\title{
EXTRATO DO RELATÓRIO DO SECRETÁRIO DA FACULDADE DE DIREITO DA UNIVERSIDADE DE SÃO PAULO
}

$$
1952
$$




\section{I R E T O R I A}

Exercida, durante o ano de 1.952, pelo Prof. Braz de Sousa Arruda.

\section{O N GR E G A Ç ÃO}

Foram realisadas 14 sessões da Congregação durante o ano de 1952.

\section{1.a SESSÃO : 7-2-1952}

Declaram-se prontos para o serviço os seguintes professores presentes a esta reunião: J. J. Cardozo de Mello Neto, Vicente Ráo, Waldemar Ferreira, Mário Masagão, Jorge Americano, Honório Monteiro, Lino Leme, Noé Azevedo, Soares de Mello, Cesarino Junior, Basileu Garcia, Ataliba Nogueira, Siqueira Ferreira, Miguél Reale, Th. Monteiro de Barros Filho, Almeida Jr. e os livres docentes Silvio Marcondes Machado, Goffredo da Silva Telles, Jr. e Luís Eulálio de Bueno Vidigal. Não compareceram à reunião, por motivo de força maior, tendo enviado comunicação que também se achavan prontos para o serviço os professores Gabriel de Rezende Filho, Alexandre Correia, Soares de Faria e J. C. Mendes de Almeida e os livres docentes Pinto Pereira e Gama e Silva.

O Prof. Braz Arruda declara que iria submeter à apreciação da Casa os diversos ante-projetos apresentados, sôbre a reforma do Curso de Doutorado. Deliberou-se, entretanto, que fosse convocada uma sessão especial para tratar desse complexo assunto.

\section{2.a $\mathrm{SESSÃO}:$ 14-2-1952.}

Esta sessão foi convocada especialmente para deliberar-se sobre o Curso de Doutorado.

Pelo Prof. Miguel Reale foi dito que estudara os diversos projetos apresentados, os quais lhe suscitaram várias dúvidas; entre estas as de maior importância são a competência do Estado para legislar sôbre o assunto e a inexišstência da seriação do curso na lei 
3023. Assim, no seu modo de ver, o art. 10 do decreto 7068 de 6-4-1935 foi revogado pelo art. 12 de lei 3023. Dêste modo, a deliberação do Conselho Técnico, em 1947, resolvendo aplicar no Curso de Doutorado a seriação federal, com o acréscimo da cadeira de História do Direito Nacional, foi melhor possível. Não havendo lei estadual deve aplicar-se a federal, Nestas condições, resolveu apresentar à Congregação a seguinte proposta:

“Considerando que a matéria concernente à organização do currículo do Curso de Doutorado é de competência da legislação federal;

Considerando que os atuais alunos do Curso de Doutorado fizeram o curso de acôrdo com o art. 10: do antigo regulamento da Faculdade de Direito, proponho:

1) que se aplique, desde logo o curriculo estabelecido na lei federal, possibilitando-se, dess'arte, aos atuais e futuros alunos a escolha de uma das seções do Curso de Doutorado, acrescida a cadeira de História dó Direito Nacional, na forma da resolução tomada pelo C. T.A. em 1947.

2) que se confira ao C.T.A. a incumbência de reajustar os cursos do presente ano letivo, de maneira que os atuais alunos satisfaçam as exigências da lei federal."

O Prof. Ataliba Nogueira dá seu voto favorável à proposta do Prof. Reale.

Pelo Prof. Sampaio Dória foi dito que, pela Constituição de 1946, cumpre ao Estado de São Paulo organizar o seu sistema de ensino, segundo o art. 171, que reza:

“Os Estados e o Distrito Federal organizarão os seus sistemas de ensino",

No art. 168, a Constituição estabeleceu princípios obrigatórios aos sistemas de ensino, quer estaduais, quer federais. Declara êste artigo :

"Art. 168 - A legislação do ensino adotará os seguintes princípios :

I - O ensino primário é obrigatório e só será dado na língua nacional;

II - O ensino primário oficial é gratuito para todos; o ensino oficial ulterior ao primário sê-lo-á para quantos provarem falta ou insưficiência de recursos; 
III - As empresas industriais, comerciais e agrícolas, em que trabalham mais de 100 pessoas, são obrigadas a manter ensino primário gratuito para os seus servidores e os filhos dêstes;

VI - As empresas industriais e comerciais' são obrigadas a ministrar, em cooperação, aprendizagem aos seus trabalhadores menores, pela forma que a lei estabelecer, respeitados os direitos dos professores;

$\mathrm{V}$ - O ensino religioso constitue disciplina dos horảrios das escolas oficiais, é de matrícula facultativa, e será ministrado de acôndo com a confissão religiosa do aluno, manifestada por êle, se capaz, ou pelo seu representante legal ou responsável;

Ví - Para o provimento das cátedras no ensino secundário oficial e no ensino superior oficial ou livre, exigir-se-á concurso de títulos e provas, será assegurada a vitaliciedade;

VII - E garantida a liberdade."

O texto tem caráter imperativo: organizará é tempo futuro e modo positivio. Não se faculta, apenas, como se estivesse o texto redigido: cada Estado poderá organizar; não somente poderá, mas organizará.

Até hoje nada se organizou.

Há quem suponha que o cumprimento do imperativo do art. 171 está condicionado ao estabelecimento por lei ordinária das bases e diretrizes do ensino.

E mero engano. Os preceitos constitucionais devem ser cumpridos independentemente de usar ou não, o Congresso Nacional, a atribuição que lhe confere o art. 50 , no $\mathrm{XV}$, letra $C$.

As bases existem no art. 168. O Ciongresso poderá legislar sôbre novas bases, sem desrespeito das existentes. Mas o art. 171 tem aplicação independente de exercer, oư não, o Congresso, a faculdade que the confere o art. $50, \mathrm{n}^{\circ} \mathrm{XV}$, acima referido.

A meu ver o que está em vigor é o seguinte:

10) O Estado de São Paulo, como outro qualquer estado e o Distrito Federal, está no dever de organizar seu sistema de ensino, sistema próprio.

20) Na falta, será aplicado o sistema federal, supletivamente, conforme dispõe o art. 170. 
Continuam os debates, usando da palavra os Profs. Ataliba Nogueira, Almeida Jr., Cesarino Jr., Jorge Americano, Miguel Reale, Basileu Garcia, Waldemar Ferreira e outros, diversos dos quais manifestaram as suas dúvidas quanto à revogação do art. 10 do decreto 7068 .

O Prof. Honório Monteiro propõe que se conceda ao C. T. A. adferendum da Congregação, a incumbência de estudar o assunto, suprindo a nomeação da comissão. O Conselho verificará, tambem, a possibilidade de adaptação do curso atual ao federal.

Sôbre esta proposta, falam os Profs. Ataliba Nogueira, Almeida Jr., Waldemar Ferreira, Basileu Garcia, Miguel Reale, Cesarino Jr. e Jorge Americano.

O Prof. Miguel Reale resolveu retirar a sua proposta.

Assim, foi submetida a votos a proposta do Prof. Honório Monteiro e aprovada contra um voto. 0 Prof. Jorge Americano declarou que votou a favor da proposta Honório Monteiro, visto ter o Prof. Reale retirado a sua proposta.

O Sr. Diretor declarou que convacaria o C. T. A. para o dia 19 do corrente, afim de deliberar sobre o assunto.

\section{SESSÃO: 3-4-1952.}

o Sr. Diretor explica os motivos qưe determinaram a convocação dos srs. professores. Assim, comunica que o C. T. A., em sessão de $1 .^{\circ}$ do corrente, resolveu, ad referndum da Congregação, tresdobrar as aulas do $1^{\circ}$ ano do Curso de Bacharelado, afim de admitir à matricula todos os aprovados no concurso de habilitação, em número de 418. Comunica, ainda, o Sr. Diretor, outra deliberação do $\mathrm{C}$. T. A. relativa à remuneração idos srs. professores que examinaram no concurso de habilitação.

Nesta sessão foram apresentadas e aprovadas as seguintes propostas :

- dos Profs. Vicente Ráo e Soares de Mello no sentido de que seria oportuno debater-se no Congresso dos Reitores a denominação de Universidade do Brasil e de Faculdade Nacional de Direito, pois nacionais todas são, especialmente as de São Paulo e Recife, e a denominação de Universidade do Brasil que apenas neste país é usada, porque as universidades sempre tomaram os nomes de suas cidades, como a de Paris, a de Roma, e de Coimbra, e assim por diante.

- do Prof. Waldemar Ferreira, no sentido de que se reserve o próximo número da "Revista" da Faculdade, para comemorar o 
250 aniversário de professorado dos catedráticos Sampaio Dória e Vicente Ráo.

\section{$4^{\mathrm{a}}$. SESSÃO： 5-5-1952.}

Pelo Sr. Diretor foi dito que a inscrição para concurso para professor catedrático de Direito Internacional Privado, encerrado no dia 3 do corrente, concorreram cinco candidatos, os bachareis Antônio Chaves, Plínio Balmaceda Cardozo, Luís Araujo Cónreia de Brito, Nicolau Nazo e livre docente Dr. Luis Antônio da Gama e Silva.

Passou a Congregação a verificar se estavam formalmente preenchidas as condições de inscrição e a decidir sôbre a idoneidade dos candidatos. Em votação separada e secreta para cada concorrente foram aceitas todas as inscrições, unanimemente.

Em seguida, a Congregação elegeu os Profs. Vicente Ráo, Hónório Monteiro e Lino Leme, êste suplente, para examinadores do mesmo concurso. Resolveu, mais, a Congregação, realizar o concurso em setembro dêste ano. Resolveu, ainda, realizar os concursos à livre docência, em que se acham inscritos os bachareis José Cretela Jr. e Silvio Rodrigues, no dia 20 de junho próximo.

Usou, então, da palavra, o Prof. Miguel Reale, para participar à Douta Congregação ter a honra de representar a Faculdade de Direito em dois congressos realizados na Italia, o primeiro destinado ao debate do tema "Cristianismo e Razão de Estado" e o segundo, em comemoração do oitavo centenário do "Decretum" de Graciano - pedra angular do direito canônico; no primeiro dos congressos apresentou um estudo focalizando o problema do cristianismo e a razão de estado no renascimento luziada, tendo tido, ainda, oportunidade de realizar conferências em Gênova, Bolonha e Lisboa.

\section{SESSÃO: 29-5-1952.}

O Sr. Diretor, deu ciência à Congregação dos artigos publicados na Tribuna Acadêmica por diversos alunos. Disse o Sr. Diretor que, deante da gravidade das acusações feitas pelos mesmos a professores e funcionários da Casa, convocara o C.T.A., perante o qual prestaram declarações alguns alunos, declarações essas que foram lidas, hem como os artigos publicados. Ciente a Congregação, deliberou esta aguardar o resultado da sindicância determinada pelo C. T. A., e entregue aos professores Alvino Lima e Basileu Garcia.

Usaram da palavra, sồbre êste assunto, diversos professores, tendo o Prof. Almeida Jr. declarado que é necessário punir os 
culpados, mas, que a seu ver, a profilaxia é mais importante do que a terapêtica, e, portanto, escreverá algumas indicações de caráter prático sôbre a questão, que fará chegar às mãos dos professores encarregados da sindicância e dos demais colegas.

O Prof. Ataliba Nogueira fez um apelo ao Sr. Diretor, no sentido de ser apressada a aprovação do regimento dos auxiliares dé ensino, entregue ao Conselho Universitário, os quais poderiam colaborar com os professores na repressão aos fatos mencionados.

O Sr. Diretor respondeu declarando que trataria de apressar a aprovação do regimento e deu ainda iniorormações ao Prof. Siqueira Ferreira relativas à exigência de prova de identidade nos exames. escritos e orais.

Em seguida, a Congregação procedeu à eleição dos nomes a serem enviados à Reitoria para renovação do C. T. A., no qual concluirão em 30 de Junho os respectivos mandatos os Profs. Sampaio Dória e Alvino Lima. Procedida à eleição, em escrutínio secreto, obtiveram maioria de votos os Professores Jorge Americano, Miguel Reale, Waldemar Ferreira e Almeida Jr. De acôrdo com a lei, êsses nomes seriam enviados para nomeação, à Reitoria da Universidade.

Nesta sessão foi presente à Congregaçã்o o parecer do Prof. Honório Monteiro, aprovado pelo C. T. A., relativo ao curso de doutorado, parecer que conclue da seguinte forma:

- "O Curso de Doutoramento deve ser mantido com o curriculo previsto nos estatutos de nossa universidade, que é o mesmodo decreto estadual 70638, de 6 de abril de 1935."

O parecer do Prof. Honório Monteiro foi submetido à votação. Pediu a palavra o Prof. Vicente Ráo, para propor que todo o material relativo ao curso de doutorado voltasse ao C. T. A., para que dêste elabore um ante-projeto de reforma do curso, a ser enviado. ao poider legislativo.

\section{6a. SESSÃO: 10-6-1952.}

O Sr. Presidente anunciou o primeiro assunto da ordem do dia: indicação de dois nomes para o cargo de Diretor, visto o mandato do atual diretor terminar no dia 23 do corrente.

Procedida à eleição, em escrutínio secreto, dos dois nomes a serem enviados ao Govêrno do Estado, para o cargo de diretor, nos termos do decreto estadual no 15.610, de 26-1-1946, verificou-se que obtiveram maioria de votos os Profs. Braz de Sausa Arruda, 19 (dezenove) votos e Jorge Americano, 6 (seis) votos. 
Passou-se, em seguida, à eleição dos dois nomes para o provimento da função de Vice-Diretor, tendo-se verificado o seguinte resultado: - Prof. Honório Monteiro, 11 (onze) votos; Prof. Alvino Lima 11 (onze) votos.

Pelo Sr. Presidente foi dito que encaminharia ao Magnífico Reitor os nomes indicados e agradeceu à Congregação a Votação que lhe fora atribuida, declarando que tudo faria para bem servir à Faculdade.

Passou a Congregação a organizar os temas para as provas escritas dos concursos à livre docência de Direito Administrativo e Direito Civil, aos quais concorrem, respectivamente, os bachareis José Cretela Jr. e Silvio Rodrigues.

Organizados os temas, a Congregação mandou colocá-los à disposição dos candidatos, a partir dessa mesma data, realizando-se as provas escritas no dia 21 do corrente, às 8 horas.

Em seguida, foi posta em discussão a deliberação do Conselho Técnico-Administrativo, relativa à desapropriação de prédios da R. Riachuelo.

\section{7a. SESSÃO：26-6-1952.}

O Prof. Cardoso de Mello Neto leu o parecer relativo ao concurso à livre docência de Direito Administrativo, encerrado nessa data, ao qual concorreu o Bel. José Cretela Jr., parecer êsse que conclue pela inhabilitação do candidato.

0 parecer, tendo sido submetido a votos, foi unanimemente aprovado.

\section{8a. SESSÃO：2-8-1952.}

Pelo Sr. Diretor foi dito que convocara a Congregação para proceder à eleição do representante da Faculdade no Conselho Nacional de Educação, nos termos da lei 174, de 6-1-1936, e conforme conta do proc. $12.098 / 51$, da Reitoria da Universidade.

Procedida à votação, em escrutínio secreto, verificou-se ter obtido maioria de votos o Prof. Almeida Jr., 14 (catorze) votos.

\section{9a. SESSÃO: 25-8-1952.}

o Prof. Almeida Jr., fêz ưm relatório, à Congregação, a propósito das irregularidades ocorridas na organização das listas para renovação do Conselho Nacional de Educação. 
A Congregação resolveu, votar artigo por artigo, do ante projeto de organização do Curso de Doutorado salvo as emendas apresentadas. Ficou o mesmo com a seguinte redação final:

ANTE-PROJETO DA ORGANIZAÇÃO DO CURSO DE ESPECIALIZAÇÃO E DOUTORADO:-

Art. $1^{\circ}$ - É mantido, com a denominação de curso de especialização e doutorado, o atual curso de doutorado da Faculdade de Direito da Universidade de São Paulo.

Art. $2^{\circ}-01^{\circ}$ ano do curso será comum a todos os alunos e haverá um $2^{\circ}$ ano destinado à especialização em ciências juridicas e socias, compreendendo quatro secções de livre escolha.

Art. $3^{0}-0$ curso, de preferência monográfica, terá as seguintes cadeiras:

\subsection{Ano:}

Filosofia e Sociologia Juridica

História do Direito Nacional

História das Doutrinas Políticas

\section{2o ANo}

1a secção: Direito Civil Comparado

Direito Comercial Comparado

Teoria do Processo Civil

$2^{a}$ secção: Direito Penal Comparado

Criminologia

Teoria do Processo Penal

3a. secção: Direito Público (Teoria Geral do Estado)

Onganização Internacional

Economia e Legislação Social

4a. seção: Ciência da Adminisitração

Direito Financeiro

Política Econômica e Financeira

Art. $4^{\circ}$ - Somente os bachareis em ciências jurídicas e sociais poderão inscrever-se neste Curso.

Art. $5^{\circ}$ - E facultada a matrícula em uma ou mais cadeiras do Curso, até o máximo de três, da mesma secção ou de secções diferentes. 
Art. $6^{\circ}$ - A regência das disciplinas caberá a professores catedráticos do Curso de Bacharelado, designados pela Congregação, ressalvado o exercício dos professores catedráticos nomeados para o antigo Curso de Doutorado.

§ único: A critério da Congregação, poderão ser contratados professores nacionais ow estrangeiros.

Art. $7^{0}-O$ Curso será ministrado em duas aulas semanais, havendo trabalhos de seminário e pesquisas.

Art. $8^{\circ}-$ Em cada cadeira o aluno apresentará, até o último dia do periodo letivo, uma dissertação escrita, sôbre a qual será argüida pela comissão examinadora.

Art. $9^{\circ}-O$ aluno, aprovado no 10 ano e em qualquer das stecções do $2^{\circ}$ ano, receberá certificado de conclusão do curso.

$\S$ único: $O$ aluno que na forma do art. $5^{\circ}$, se matricular em uma ou mais cadeiras, uma vez aprovado nos exames, receberá o respectivo certificado de aprovação.

Art. $10^{\circ}$ - A defesa de tese, destinada à obtenção do título de doutor em ciências juridicas e sociais, oferecerá à legislação vigente.

Art. $11^{\circ}-\mathrm{O}$ ano letivo, regime de frequência, elaboração de programas, inscrição em exames, substituição de professores e demais exigências regulamentares, obedecerão ao estatuido para o Curso de Bacharelado.

Art. $12^{\circ}$ - Os alunos que, na data da publicação desta lei, se encontrarem matriculados no $1^{\circ}$ ano, concluirão êste ano do Curso em conformidade com o regime anterior e se matricularão no $2^{\circ}$ ano, de acôrdo com a presente lei.

$\S$ único: - Fica ressalvado aos bacharelandos já inscritos no $1^{0}$ ano o direito de prosseguir no curso.

Art. $13^{\circ}-$ Os alunos matriculados no $2^{\circ}$ ano, na data da publicação desta lei ficam dispensados, na secção que escolherem, das provas relativas a matéria em que já houverem sido aprovados no regime da lei anterior, cabendo-lhes prestar exames das demais matérias, na qualidade de dependentes.

Art. $14^{\circ}$ - As despesas decorrente do funcionamento dêste Curso correrão pelas verbas próprias da Universidade de São Paulo.

Art. $15^{\circ}$ - Esta lei entrará em vigor na data de sua publicação, revogadas as disposições em contrário.

\section{0a. SESSÃO：25-9-1952.}

O Centro Acadêmico "XI de Agosto" solicitou o Salão Nobre da Faculdade para a sessão inicial da II Semana de Estudos Juri- 
dicos, devido aos trabalhos da mesma e ao grande número de professores e estudantes de outras Faculdades, convidados para tomar parte na aludida reunião. Solicitou, também, suspensão das aulas.

A Congregação resolveu atender ao pedido e suspender as aulas.

Em seguida, a Congregação ouviu a leitura, pelo Sr. Secretário, do relatório do perito Júlio Pinheiro de Carvalho, sôbre a revisão da contabilidade e respectiva documentação da fundação "Prêmio Carvalho de Mendonça", relatório inteiramente favorável às referidas contabilidade e documentação, as quais consignam a verdadeira situação da fundação.

A Congregação aprovou, unanimemente, o relatório, tendo-se abstido de votar o Prof. Honório Monteiro, por ser um dos administradores da fundação.

Pediu a palavra o Prof. Soares de Mello, para propor que a Diretoria providenciasse a organização do catálogo do patrimônio artístico da Faculdade, a exemplo dos que existem em Coímbra, Porto e Lisboa, e mais, que com o tempo e possibilidades orçamentárias, tivessem todos os professores os seus retratos nas salas da Faculdade, podendo ser feitos, em primeiro lugar, os retratos dos professores aposentados, em seguida os daqueles que concluiram vinte e cinco anos de exercício, completando-se, dêste modo, a galeria dos professores da Academia. Propôs mais, o Prof. Soares de Mello; que a Diretoria providenciasse a restauracão dos quadros existentes na Faculdade.

\section{1. ${ }^{\mathrm{a}}$ SESSÃO : 2-10-1952}

A Congregação tomou conhecimento da inscrição do bacharel José Frederico Marques no concurso à livre docência de Direito Judiciário Penal.

Passou, então, a eleger em escrutínio secreto, os examinadores para o referido concurso, tendo obtido maioria de votos, os seguintes professores:

Prof. J.C. Mendes de Almeida

Prof. Basileu Garcia

Prof. Gabriel de Rezende Filho

- 20 votos

Prof. José Soares de Mello

- 17 votos

Prof. Noé Azevedo

- 14 votos

Prof. Ataliba Nogueira

- 13 votos

Prof. Siqueira Ferreira

- 13 votos

- 8 votos

- 5 votos 
Resolveu, mais, a Congregação, realizar o concurso em Março de 1953, aprovando proposta do Proif. Gabriel de Rezende Filho.

Foi em seguida, presente à Congregação, o seguinte requerimento do Prof. Siqueira Ferreira:

"Exmo. Sr. Doutor Diretor da Faculdade de Direito da Universidade de São Paulo.

Requeiro a V. Excia. se dígne submeter á inclusa proposta ao exame e deliberação da primeira Congregação de professores que se realizar, se não entender V. Excia., que, dada a gravidade do assunto, uma extraordinária, com urgência, deve ser convocada.

São Paulo, 3 de Setembro de 1952.

as) Siqueira Ferreira

Egrégia Congregação da Faculdade de Direito de São Paulo.

"O Hymno Academico faz parte do patrimonio da Faculdade de Direito; é de sua propriedade artística e literaria, garantida por nossa legislaçẫo."

"Ultimamente pensou-se em adoptar a canção como hymno da Universidade. Levada a ideia ao Conselho Universitario, deliberouse alli substituirem-se as estancias, abrindo-se para isso concurso entre os poetas do dia"

"A deliberaç̃o provocou geraes protestos e decisiva repulsa. o Reitor da Universidade não abriu o concurso; a Faculdade de Direito tornou publico que de modo algum consentiria em semelhante cousa; a mocidade da gloriosa Academia clamou vehemente. A ideia sucumbiu nem bem nascida."

"Em Congregação dos Professores, celebrada em $1^{\circ}$ de fevereiro p.p., fizemo-lhes a seguinte comunicação:

"Participou o Dr. Director que, relativamente à lembrança que levara ao Conselho Universitario de adoptar-se como hymno da Universidade o hymno academico da Faculdade de Direito, musica de Carlos Gomes e letra de Bittencourt Sampaio, vae propor ao mesmo Conselho fique sem effeito a idéia, à vista da infeliz deliberação que alli se tomara, de abrir-se concurso para a composição de uma nova lettra, substitutiva da tradicional.

A Faculdade não pode apadrinhar as críticas desarrazoadas que têm alguns feito às históricas estrophes de Bittencourt Sampaio, nem consentir que se mutile o hymno, alterando-lhe ou substituindo-lhe as estancias e estribilhos. Como Director, vae pedir ao Conselho que desista da ideia e, se o Conselho persistir, tratará de impedir, ainda que por meios judiciais, que se cante officialmente 
a composição de Carlos Gomes em letra extranha. O hymno faz parte da propriedade artística da Faculdade e o hymno, como propriedade, é o conjunto da musica e dos versos que se compuzeram originalmente. A Congregação aprovou, tambem por unanimidade de votos, o modo de ver e a atitude do seu Director".

"O Hymno Academico é hoje, como sempre foi, propriedade exclusiva da Faculdade de Direito, com a mesma lettra e musica com que apareceu em 1859".

Assim é; e assim há de sempre ser".

Isto foi o que disse e esta foi a atitude que, em 1937, assumiu o Prof. Francisco Morato.

Repete-se agora a tentativa de esbulho, como noticiam os jornais, com a agravante de ser o Conselho Universitário presidido por um Professor desta Casa, alarmante sintoma de como mudam os tempos.

A beca dos professores de Direito já se alastrou pela Universidade, proliferando de tal modo que a veste talar, tradicional apanágio dos médicos e dos juristas, abriga hoje, num espantoso ridiculo, até quem, no campo, empunhando o arado, ministra lições de como se deve amanhar a terra. .

A Faculdade de Direito está mal instalada, proclama notável professor de Farmácia; é preciso que prédios sejam desapropriados para suas novas instalações.

Dia virá em que os donos da Universidade de São Paulo entenderão que devem vir nos ensinar como deveremos ensinar o Direito.

Confiar-se-á talvez a tarefa ao talento de conhecido professor de veterinária, que já ensaiou seus primeiros voos no assunto, esbocando sua transcedental "teoria da retroatividade das leis futuras".

Não lhe parece, Egrégia Congregação, que chegado é o momento do "quousque tandem"?

Assim requeiro a nomeação de uma Comissão de Professores que, se inteirando da realidade dos fatos e estudando o assunto, proponha as medidas cabiveis antes que alguem lamente:

Pobre Faculdade de Direito de São Paulo.

as) Siqueira Ferreira"

Pediu a palavra o Prof. Theotônio Monteiro de Barros Filho e por êle foi dito que êste assunto já fôra levado ao Conselho Universitário, por intermédio do representante dos alunos, que transmitiu ao Conselho um protesto do Centro Acadłâmico XI de Agnsto. $O$ Magnificico Reitor nomeara os Professores Jaime Cavalcanti, Milton 
Rodrigues e o declarante para, em comissão, estudarem o assunto. E bem certo, continuou S. Excia., que, no Conselho, representa a Faculdade de Ciências Econômicas. Mas, está aqui a sua Casa. Trata-se de assunto essencialmente afetivo, e, pois, não tinha dúvidas. em antecipar o seu voto inteiramente ifavorável aos protestos dos. rapazes do Centro Acadêmico "XI de Agosto". Se o Conselho Universitário entendesse de adotar o hino, letra e música, receberia a deliberação como uma deferência. Porém, com outra letra, não. $O$ argumento que mais se usa contra a letra do Hino Acadêmico é de que ela é absoluta. Ao seu ver, todas são. Elas ficam presas, via de regra, a um momento histórico e representam o sentimento total de uma nação, em determinada hora. Emocionalmente, são um marco na vida de um povo. $O$ hino acadêmico é um pouco da participação desta Casa na História do Brasil e mais, uma demonstração de como a Faculdade de Direito vibra uníssona com a Pátria.

Não vê, portanto, como se possa alterar a letra do Hino Aca- dêmico. Entretanto, deseja conhecer o pensamento da Congregação, para melhor traduzi-lo junto ao Conselho Universitário.

O Prof. Ráo declara que subscreve inteiramente a proposta do Prof. Siqueira Ferreira.

A proposta do Prof. Siqueira Ferreira foi posta a votos, tendo. sido aprovada unanimemente.

\section{2a. SESSÃO： 23-10-1952.}

Aberta a sessão, foi lido o telegrama do Prof. Albérico Fraga, da Faculdade de Direito da Bahia, comunicando a impossibilidade deexaminar no concurso para a cátedra de Direito Internacional Privado. A Congregação entendeu que o assunto deve ser submetido ao Conselho Técnico-Administrativo, ao qual compete a indicação de nomes para completar a comissão examinadora.

Em seguida foi lido o requerimento em que o Bel. Plinio Balmaceda Cardoso pede o cancelamento de sua inscrição no concurso para professor catedrático de Direito Internacional Privado.

Foi presente à Congregação a deliberação do Conselho Técnico e o requerimento do Prof. Siqueira Ferreira sôbre o contrato do livre docente Almeida Amazonas, para dar um curso prático de. Processo Civil.

Em seguida, a Congregação ficou ciente do processo no 4467/49. da Reitoria da Universidade, relativo ao livre docente nomeado para professor catedrático, e da deliberação do Conselho Universitário sôbre o mesmo processo.

Em seguida, lido o pedido do Prof. Jorge Americano sôbre o. projeto de lei 1095, que trata da criação dos cargos de professor- 
adjunto na Universidade, a Congregação resolveu que o assunto fosse submetido a uma comissão.

O Sr. Diretor designou os Profs. Cardozo de Mello Neto, Gabriel de Rezende Filho e Basileu Garcia para comporem a referida comissão.

Em seguida, passou-se à discussão dos pareceres apresentados pelos Profs. Cardozo de Mello Neto, Waldemar Ferreira e Basileu Garcia, sobre o projeto de lei relativo à criação de seminários na Faculdade.

Discorrem sôbre o assunto diversos professores, tendo o Prof. Almeida Jr. proposto que, com os pareceres, a Congregacão comunicasse à Reitoria que, sendo a matéria do projeto 1.300 um assunto de caráter didático, e por isso mesmo abrangido na autonomia universitária, não seria acertado que o Poder Legislativo procurasse discipliná-lo.

Encerrados os debates, foram submetidos a votos os pareceres ne o acréscimo do Prof. Almeida Jr., e aprovados, contra o voto do Prof. Cesarino Jr.

Pelo Prof. Miguel Reale foi dito que o seu voto quanto ao projeto de lei que possibilita a criação de seminários foi no sentido da inoportunidade da medida, que deverá ser apreciada conjuntamente com o projeto da criação dos cargos de professores adjuntos.

o Prof. Miguel Reale requereu que fosse nomeada uma comissão que se entendesse diretamente com a Assembléia Legislativa sôbre os projetos de lei criando as cadeiras de Direito Municipal e Legis"lação Penitenciária nesta Faculdade.

Aceita a proposta, Sr. Diretor designou os Profs. Waldemar Ferreira, Honório Monteiro e Miguel Reale para comporem a refe- rida comisão.

\section{3a. SESSÃO： 27-11 1952.}

Foi nesta sessão discutido o assunto sôbre prestação de exames parciais, do $2^{\circ}$ período, por parte de alunos que não foram frequentes às aulas, e tambem por parte de alunos dependentes.

Vários professores apresentaram propostas sôbre essa matéria.

Foi aprovada uma proposta do Prof. Waldemar Ferreira do eguinte 'teor:

"Não serão admitidos à segunda prova parcial (escrita) os alunos que não tiverem frequência na respectiva cadeira"

o Prof. Reale propõe o seguinte acréscimo a esta proposta: “ . respectiva cadeira, sem prejuizo dos' alunos dependentes". 
Submetida a votos a proposta do Prof. Waldemar Ferreira, com acréscimo do Prof. Reale, foram ambos aprovados por onze votos contra seis.

O Prof. Siqueira Ferreira propõe que as medidas aprovadas tenham execução a partir de 1953.

o Prof. Vicente Ráo pede preferência, que lhe é concedida, contra dois votos, para a votação da parte final da slia declaração de voto do seguinte teor:

"Reputo, pois, dispensado de frequência nas cadeiras de que depende, o aluno matriculado no ano imediatamente superior, em caso de incompatibilidade de horário, apurada pelo Conselho Técnico. Administrativo."

Submetida a votos, esta proposta foi aprovada contra quatro yotos.

o Prof. Siqueira Ferreira declarou o seguinte:

"Voto contra, porque havendo cursos diurno e noturno, não se pode falar em incompatibilidade de horários. Não é possível julgar contra a evidência".

O Prof. Honório Monteiro propõe que, de agora em diante, os dependentes do curso diurno frequentem o curso noturno, e, os do curso noturno, o diurno, afim de não coincidirem os horários.

O Prof. Almeida Jr. declara que o curso noturno foi instituido com um propósito bem definido: - facilitar o estudo aos alunos que trabalham durante o dia. Confessa que recebeu os alunos com certa prevenção, pois, entendia que não teriam tempo, nem disposição para estudar. Pois agora, está convencido de que os alunos dão boa conta da tarefa. Assmi, justifica o seu voto contrário à proposta Honório Monteiro.

O Prof. Cesarino Jr. e o Prof. Miguel Reale votam de acôrdo com o Prof. Almeida Jr., declarando o Prof. Reale que não é possivel recusar-se o que a lei concede.

Submetida, então, a votos, a proposta Honório Monteiro, foi ela aprovada contra quatro votos.

Em seguida, foi presente à Congregação o parecer dos Profs. Honório Monteiro e Miguel Reale e o voto vencido do Prof. Waldemar Ferreira, sôbre o projeto de lei criando a cadeira de Direito Municipal nesta Faculdade.

Discutido o assunto, por diversos professores, foi, afinal, submetido a votos o parecer Honório Monteiro - Miguel Reale, e aprovado contra três votos. 


\section{CONSELLHO TÉCNICO-ADMINISTRATIVO}

\section{1a. SESSÃO: 29-1-1952.}

Foi deliberado pelo C. T. A. fixar o número de alunos em 300 para cada ano, sendo 200 no curso diurno e 100 para o curso noturno, não havendo vagas, não aceitar transferência, sob nenhum pretexto; não haverá férias coletivas, sem prejuizo das férias individuais dos funcionários;

O C. T. A. elegeu as seguintes comissões examinadoras para o concurso de habilitação, no corrente ano:

LATIM: Prof. Honório Monteiro e livres docentes José Antônio de Almeida Amazonas e Alexandre Augusto Castro Correia; PORTUGUES: Prof. Sampaio Dória e livres docentes Hilário Veiga de Carvalho e Alfredo Buzaid;

INGLES: Prof. Jorge Americano e livres docentes Luis Eulálio de Bueno Vidigal e Esther dde Figueiredo Ferraz;

FRANCES: Profs. Ataliba Nogueira e Almeida Jr. e livre docente Paulo Barbosa de Campos Filho;

FILOSOFIA E HISTÓRIA DA CIVILIZACÃO: Prof. Waldemar Ferreira, Cesarino Jr. e Miguel Reale.

O Conselho autorizou o Sr. Diretor a efetuar as substituições que se tornarem indispensáveis, nas comissões supra e resolveu mais: iniciar as provas escritas dos exames do concurso de habilitação no dia 16 de fevereiro próximo, realizando-se as demais nos dias 20, 21 e 22 de fevereiro; convocar todos os professores da Congregação para auxiliarem a fiscalização das provas escritas; distribuir ao Prof. Basileu Garcia diversos pedidos de transferência de funcionários públicos, afim de que dê parecer ao Conselho; aprovar proposta do Prof. Sampaio Dória no sentido de que a Congregação considere os preceitos da Constituição de 1946, sôbre competência para a legislação do ensino, discriminando o que cabe là União, o que cabe aos Estados e o que ficou reservado às Universidades.

\section{2a. SESSÃO: 19-2-1952.}

0 Conselho deliberou: - fechar a Faculdade de 23 de Fevereiro e 2 de Março, afim de dar-se um descanço aos professores e funcionários; 
- com referência aos pedidos de transferências de funcionários públicos, que os mesmos devem provar a anterior lotação no Distrito Federal ou em Niteroi, durante o ano de 1951 e o efetivo exercicio do cargo; - deferir um requerimento de transferência de um interessado, por se achar provada a exigência da deliberação supra;

— indeferir outros requerimentos de transferência, por não haver vaga, conforme deliberação anterior;

- realizar a aula inaugural no dia $1^{\circ}$ de Abril.

Em seguida, o Sr. Diretor lembrou a conveniência de serem consultados professores de outras Faculdades, sôbre se aceitariam o convite para comporem a comissão examinadora do concurso para professor catedrático de Direito Internacional Privado, lembrando, entre outros, os nomes dos Profs. Amilcar de Castro, Albérico Fraga e Sergio Loreto Filho, com os quais concordou o Conselho.

Consultou ainda o Sr. Diretor o Conselho, sôbre o regulamento dos auxiliares de ensino. 0 Conselho resolveu que o mesmo fosse enviado ao Magnifico Reitor, para os devidos fins.

Ciente do ofício da Reitoria relativo à vinda de professores estrangeiros a São Paulo, o Conselho deliberou apresentar. oportunamente, os nomes solicitados.

Passou o Conselho a considerar o apêlo do Prof. Waldemar Ferreira, sôbre a desapropriação de prédios da R. Riachuelo, afim de ampliar-se o edifício desta Faculdade, resolvendo distribuir os papeis respectivos, inclusive as informações do Sr. Diretor. ao Prof. Honório Monteiro, para estudar o assunto e apresentar ao Conselho as suas conclusões.

Logo após, o Conselho passou a considerar a deliberação da Congregação que, em 14 do corrente, resolveu atribuir ao Conselho Técnico a incumbência de, ad referendum da Congregação, estudar os asuntos relativos ao Curso de Doutorado verificando a possibilidade de adaptação do curso atual ao sistema federal.

\section{3a. SESSÃO: 27-3-1952.}

Deliberações do Conselho:

- indeferir os pedidos de inscrição para exames da 2a. época, encerrada em 10 do corrente, feito por diversos alunos. por se acharem fora do prazo da inscrição;

-. confirmar a decisão anterior sobre os exames dos alunos que pertencem ao C.P.O.R., relativa a um estudante, decisão essa tomada na sessão de 6-12-1948; 
- sôbre transferências para esta Faculdade, deferir requerimentos de dois interessados, que apresentaram prova necessária, e indeferir um outro.

Em seguida. considerando que, de acôrdo com o decreto 21.292. de 19-3-1952. existe uma verba especialmente determinada ao pagamento do serviço extraordinário do concurso de habilitação, que constitui um onus para os professores que desta tarefa se incumbem;

- considerando que a remuneração em apreço existe eu outros institutos da Universidade de São Paulo;

- considerando que, de acôrdo com o art. 17, letra F, da lei 3023, incumbe ao Sr. Diretor autorizar êsse pagamento;

- considerando, entretanto, que o Sr. Diretor preferiu ouvir a respeito do assunto o $\mathrm{C}$. $\mathrm{T}$. A.;

- resolve o Conselho Técnico-Administrativo:

- estabelecer que, a partir do presente exercício, se pague a todos os professores componentes das bancas examinadoras, diárias de 400,00, como remuneração dos serviços prestados durante - tempo dos exames, acrescidos de um limite de seis diárias relativas à correção das provas escritas. O Conselho Técnico-Administrativo resolveu dar ciência desta sua deliberação à Congregação da Faculdade.

- autorizou ainda o Conselho o pagamento de $1 / 3$ dos respectivos vencimentos dos funcionários efetivos, contratados e diaristas da Faculdade, que prestaram serviços durante os referidos exames do Concurso de Habilitação.

\section{4a. SIESSÃO: $10-4-1952$.}

. Conselho Técnico-Administrativo resolveu tresdobrar as aulas do $1^{0}$ ano, afim de admitir todos os aprovados no Concurso de Habilitação, submetendo esta deliberação à Congregação da Faculdade, a qual deverá ser convocada especialmente para êste fim, na próxima quinta feira, 3 do corrente. Resolveu ainda o C. T. A.:

- indeferir um pedido de transferência;

- indeferir um pedido da revisão de provas escritas do Concurso de Habilitação, por não ser a revisão permitida pelas portarias e circulares ministeriais que tratam da matéria, nem pelo regulamento da Faculdade.

\section{5a. SESSÃO: 2-5-1952.}

Deliberações do C. T. A. 
- deferir o requerimento de um aluno no $3^{\circ}$ ano, sôbre prestação de exame da cadeira do ano, uma vez que frequentou as aulas da cadeira da qual é dependente e cujo horário coincide com uma das cadeiras do ano;

- determinar a um aluno que apresente provas de período de estágio militar;

- abonar faltas de um aluno que prestou estágio militar;

- encaminhar à Congregação recursos de dois estudantes;

— indeferir requerimento de um aluno do $3^{\circ}$ ano, sôbre revisão de provas;

- indeferir requerimento de transferência de um interessado; de Legislação Social;

- indeferir requerimento de transferência de um interessado;

- indeferir requerimentos de revisão de provas escritas e arredondamento de notas do Concurso de Habilitação de diversos candidatos, em vista das reiteradas disposições federais que regulam os assunto.

Pelo Prof. Honório Monteiro foi dito que, designado pelo C. T. A. para estudar a desapropriação de prédios da R. Riachuelo, proposta pelo Sr. Diretor ao Conselho Universitário, e por êste aprovada unanimemente, à qual se referiu o Prof. Waldemar Ferreira, em sessão da Congregação, e não tendo tido tempo de trazer por escrito o seu voto, vinha proferi-lo da seguinte forma:

Na sua opinião, o que houve foi uma iniciativa da parte do Sr. Diretor, no sentido de aumentar o patrimônio da Faculdade e ampliar as instalações desta. Não vê por que se deva exigir do Sr. Diretor a consulta à Congregação quando se trata de simples e mera iniciativa, que não escapa à sua competência, não ficando, por isso, obrigado a levá-la ao conhecimento da Congregação. Se assim agisse, o Sr. Diretor transferiria as suas prerrogativas de administrador para a Congregação. Nestas condições, entende que não há reparo nenhum a fazer à iniciativa do Sr. Diretor, devendo acrescentar que a desapropriação foi sugerida ao Conselho Universitário para ser feita, não com verba da Cidade Universitária. O projeto tratava de iniciar, com verbas próprias, a obra, e, a seguir, com o produto das heranças jacentes, completá-la. Assim, entende que a iniciativa foi boa, e termina lembrando aos Srs. Conselheiros as várias deliberações da Congregação, no sentido de não sair a Faculdade de onde está.

Pelo Prof. Honório Monteiro foi ainda dito que, tambem quanto ao Curso de Doutorado, não pudera trazer, por escrito, o seu parecer, que é o seguinte: 
Os arts. de números 11 a 17 do decreto estadual $\mathrm{n}^{\circ} \mathbf{7 0 6 8}$, de 6-4-1935, não se referem ao cúrrículo do curso de doutoramento dispondo só sôbre a parte administrativa. O que aconteceu foi que as Faculdades, de acôrdo com alei federal anterior à Constituição de 1946, poderia organizar a seriação dos seus cursos, e as que não o fizessem, adotariam os cursos federais. Decorre indagar: isto envolve a revogação do currículo estabelecido anteriormente em lei? Esta não disse que o curso obedeceria aos artigos de 11 a 17 do mencionado decreto. A seu ver, o currículo estabelecido neste decreto está em vigor. De outro modo, sỏ se poderia adotar o da lei federal.

O Governo Federal anterior ao atual, baixou um decreto permitindo que as faculdades organizassem os seus regulamentos.

Acontece que a Congregação da Faculdade Nacional de Direito não usou desta delegação. Entretanto, baixou o seu regulamento que, ao seu ver, é ideal.

Assim, entende que a Faculdade não está adstrita a esta ou aquela seriação, devendo adotar o constante do decreto 7068 (pois, alem do mais, consta do decreto ffederal no 39 , de 3-9-1934, - que aprovou os estatutos da Universidade de São Paulo), si est in quantum, encaminhando-se aos poderes competentes um projeto de lei de reforma do curso de doutoramento, medida de inteira e urgente necessidade.

O Conselho aprovou as conclusões do Prof. Honório Monteiro.

6a. SESSÃO: 28-5-1952.

O Conselho deliberou:

- deferir os pedidos de matricula no $2^{\circ}$ ano do Curso de Doutorado de dois alunos, com dependência de uma cadeira;

— indeferir requerimentos de matricula de vários bachareis, para o $1^{\circ}$ ano do Curso de Doutorado, por terem sido apresentados fora de prazo;

- indeferir requerimento de matricula de vários bachareis, por falta de amparo legal;

- determinar a um requerente para transferência, que faça prova de ser funcionário público efetivo.

O Prof. Ataliba Nogueira propoz, e foi aprovado pelo Conselho, que fosse convidado o Sr. Ministro da Educação para proferir a preleção das comemorações do dia 11 de Agosto, nesta Faculdade.

Em seguida, pelo Sr. Diretor foram presentes ao Conselho os exemplares da "Tribuna Acadłêmica", jornal que se publica nesta Faculdade, do qual constam artigos assinados por alguns estudan- 
tes, artigos esses ofensivos à Faculdade: disse, ainda, o Sr. Diretor, que convocara os referidos estudantes para comparecer à Faculdade sendo que os mesmos se achavam no edificio. Consultava, pois, o Conselho, se desejava ouvir os mencionados estudantes.

0 Conselho, ciente dos artigos, resolveu tomar as declarações dos estudantes. Depois delas, resolveu o Conselho:

- comunicar à Congregação os fatos e os depoimentos prestados;

- instaurar uma sindicância para apurar a veracidade dos fatos narrados, na qual deverão ser ouvidos, em primeiro lugar, as pessoas mencionadas pelos depoentes de hoje;

- incumbir os Profs. Alvino Lima e Basileu Garcia para procederem à referida sindicância.

\section{7a. SESSÃO: 19-6-1952.}

O Conselho deliberou:

- deferir o pedido de recondução do livre docente Hilário Veiga de Carvalho;

- conceder vista ao Prof. Honório Monteiro do pedido do livre docente J. A. Almeida Amazonas;

- encaminhar ao Prof. Basileu Garcia o processo da Reitoria da Universidade, relativo ao Curso de Doutorado;

— informar à Reitoria, nos processos ns. 3792/52 e 2802/52, que a Faculdade coloca à disposição da Reitoria as suas salas, para a realização dos cursos.

\section{8a. SESSÃO: 27-9-1952.}

Deliberação do C. T. A.: estudante;

— indeferir, por falta de apoio legal, os requerimentos de um

- suspender um estudante, por quinze dias, nos termos do art. 141 , § $1^{\circ}$, letra “d” da lei 3023 ,por ter ele usado de expressões desrespeitosas e injuriosas ao Prof. Cesarino Jr., nos requerimentos que apresentou ao C. T. A.

- oficiar ao Diretor dos Correios, afim de saber se um candidato à transferência é funcionário efetivo daquela Repartição, conforme alega em seu requerimento;

- deferir o requerimento de transferência de um aluno, por se tratar de funcionário público transferido para esta Ciapital; 
- indeferir um requerimento de transferência, por não haver vaga, conforme reiteradas decisões do C. T. A.

- indicar o nome do Desembargador Antão de Moraes, para ser convidado para completar a comissão examinadora do concurso de Direito Internacional Privado.

\section{9a. SESSÃO: 8-8-1852.}

Foram empossados nos cargos de membros do Conselho Técnido-Administrativo os Professores Jorge Americano e Miguel Reale nomeados em 30-6-1952, os quais foram saudados pelo Sr. Diretor. Os novos Conselheiros responderam, agradecendo.

Deliberou, a seguir, o Conselho:

- deferir o requerimento de transferência de um interessado. por se tratar de militar transferido de região;

- indeferir o requerimento de transferência de outro interessado, por não se tratar de transferència de funcionário público;

- deferir o requerimento de abono das faltas de um estudante, por motivo de incorporação militar;

- determinar a um aluno que faça a prova de que trata o art. 187 dos estatutos dos funcionários pủblicos;

— indeferir requerimentos de alguns alunos, por não haver terceira chamada.

Em seguida, o Prof. Honório Monteiro, designado pelo C. T. A., deu o seu parecer sôbre o pedido de contrato do livre docente Dr. J. A. de Almeida Amazonas, para ministrar um curso prático de Direito Judiciário Civil, para os alunos do $4^{\circ}$ ano. 0 parecer do Prof. Honório Monteiro conclue pela impossibilidade do Conselho Técnico-Administrativo autorizar o contrato, nor ter o livre docente ultrapassado o limite de idade, criando-se, assim, uma incapacidade para o exercício de função pública. Apesar de profundamente desagradável, reconhecendo, embora, os altos méritos e a dedicação do interessado à Faculdade, não encontrou o Prof. Honório modo de atender ao pedido, não lhe parecendo acertado a referência dos contratos de professores estrangeiros, os quais se regem, no seu modo de ver, pelo direito Civil.

O Conselho aprovou o voto do Prof. Hionório Monteiro, resolvendo, entretanto, remeter o caso à Congregação.

O Prof. Basileu Garcia, designado pelo Conselho, apresentou o seu parecer sôbre o proc. no $8081 / 52$, da Reitoria, relativo ao projeto de lei sôbre o Curso de Doutorado.

O Conselho aprovou o parecer do Prof. Basileu, com algumas alterações, parecer que resolveu submeter à Congregação, que para êsse fim especial, será convocada para dia 14 do corrente. 
Finalmente, o Conselho resolveu restabelecer o funcionamento do elevador para os estudantes, apenas do quarto de hora até o início das aulas, devido ao racionamento de energia elétrica.

\section{0a. SESSÃO: 19-8-1952.}

o Conselho deliberou:

- indeferir o requerimento de um interessado, sôbre transferência, por não se tratar de funcionário público efetivo;

- remeter à Congregação, com parecer favorável, o abaixoassinado dos alunos, pedindo que a sala de filosofia, do andar térreo, seja denominada "Sala João Arruda" Presidiu esta deliberação o Prof. Gabriel de Rezende Filho, tendo excusado de discutir e votar o assunto o Prof. Braz Arruda;

o Conselho resolveu reabrir a discussão sôbre a reforma do Curso de Doutorado, a pedido de vários conselheiros.

Reaberta a discussão, o Conselho aprovou, em sua redação final, as informações e alterações que devem ser encaminhadas à Reitoria, com o proc. no $8681 / 52$, relativo ao projeto de lei que reforma o Curso de Doutorado.

Resolveu, ainda, o Conselho, convocar a Congregação para o dia 28 , às 15 horas, afim de tomar conhecimento das deliberações desta sessão.

\section{1a. SESSÃO: 25-9-1952.}

O Prof. Braz Arruda declarou que, tendo havido um incidente entre proffessores, durante a Congregação que se realizava nessa mesma data, foi esta suspensa, tendo sido convocado o C. T. A. imediatamente, dada a urgência do caso e por se acharem presentes todos os Srs. Conselheiros, com exceção do Prof. Gabriel de Rezende Filho. O Prof. Honório Monteiro declarou - deixar de comparecer, por achar-se impedido.

\section{2a. SEISSÃO: $30-10-1952$.}

Deliberou o Conselho:

- à vista dos tèrmos dos telegramas e cartas do Prof. Albérico Fraga, - adiar a realização do concurso de Direito Internacional Privado, para depois de 5 de Abril do próximo ano, reiterando àçuele professor o convite anteriormente feito;

- fixar o prazo até 15 de Dezembro para os alunos do curso de Doutorado apresentarem os seus trabalhos, realizando-se os exames em 1a. época na segunda quinzena de Dozembro. 
- fixar o prazo até 15 de Março de 1953 para os alunos do Curso de Doutorado entregarem os seus trabalhos, realizando-se os exames em 2a. época na 2a . quinzena de Março de 1953.

Em seguida, o Sr. Diretor expoz ao Cionselho diversos fatos relativos ao servente diarista joaquim Baptista da Cruz, demitido em 14-3-1950.

O Prof. Ataliba Nogueira requereu vista do processo, para estudar o assunto, vista que lhe foi concedida.

Resolveu mais, o Conselho:

- indeferir os requerimentos sôbre faltas e exames dos alunos que pertencem ao C. P. O. R.

- indeferir requerimentos de diversos estudantes;

- solicitar ao C. P. O. R. informações sôbre diversos alunos desta Faculdade e que pertencem làquele Centro;

- determinar a um requerente, que prove a data do impedimento militar que alegou.

Quanto ao officio no 1558, da Reitoria da Universidade, o Conselho não possue elementos para deliberar sôbre o assunto.

13a. SESSÃO: 19-11-1952.

Usou da palavra o Sr. Diretor, que fez várias comunicações ao Conselho sôbre o Prof. Vampré, sôbre certidões requeridas pelo Dr. José R. Belfort de Mattos, sôbre serventes exonerados e sôbre contratos dos Profs. Barcia Trelles e Bagolini, que pretende apresentar ao Conselho.

Disse mais, o Sr. Diretor, que, em 1953, pretende realizar, nesta Faculdade, o Congresso Hispano-Luso-Americano de Direito Internacional, como o primeiro dos congressos em comemoração ao IV Centenário da Fundação de São Paulo êsse motivo, solicitava a autorização do Conselho para instalar na sala do seminário do $2^{\circ}$ andar a Secretaria do Congresso. 0 Conselho concedeu unanimemente a autorização.

Em seguida, foi presente ao Conselho um oficio do Prof. Waldemar Ferreira, sôbre a prestação de exames de alunos dependentes, sem frequência.

Sôbre o assunto discorreram todos os srs. conselheiros.

Encerrados os debates', o Conselho, unanimemente, deliberou solucionar a questão suscitada pelo prof. Waldemar Ferreira, lembrando que já existe decisã, 0 do Conselho sôbre êsse mesmo assunto, como consta da ata de 16-8-1945.

Resolveu, a seguir, o Conselho: 
- encaminhar à Congregação, com parecer favorável, a representação do Centro Acadêmico "XI de Agosto", afim de ser dado o nome do Prof. Soares de Faria à sala do Seminário de Processo Civil do $2^{\circ}$ andar;

- deferir o requerimento de prestação de exames de dependência de Direito Comercial, do $4^{\circ}$ ano, diante da resolução tomada nesta mesma sessão, de dois alunos;

- deferir os requerimentos de diversos alunos, estritamente nos têrmos dos documentos apresentados pelos requerentes;

- abonar as faltas dos estudantes a que se refere o ofício do C. P. D. R. no 1.151 , de 11-11-52, nos dias no mesmo ofício declarados;

- indeferir pedidos de revisão de provas escritas de alunos, por falta de amparo legal;

- indeferir os pedidos de abonos de faltas dos estudantes de diversos anos do Curso de Bacharelado, por falta de amparo legal.

14a. SESSÃO: 25-11-1952.

O Conselho tomou conhecimento do recurso do Prof. Waldemar Ferreira, relativo à deliberação do C. T. A., em sessão anterior, sôbre a dispensa de frequência dos alunos dependentes e resolveu:

- que, embora pareça ao Conselho que, de sua deliberação não cabe recurso algum, pois se trata de matéria de sua competência privativa, nada tem o Conselho a opor que o assunto seja submetido à Congregação; esclareceu o Conselho que, além dos argumentos já aduzidos, a deliberação se baseou no decreto nc 13.329 , de 27-4-1943, e decreto-lei no 14.037, de 20-6-44, ambos estaduais.

Deliberou mais, o Conselho:

- indeferir os requerimentos de diversos estudantes, por falta de amparo legal;

- que, nos termos do art. $1^{\circ}$ da lei federal no $1-29$, de 30-12-49. não é possivel haver promoção, por média, das provas parciais, sem o mínimo da frequência determinada em lei;

- que, a partir de 1953, ficarão excluidos da chamada da 2a. prova parcial, de novembro, os alunos que tenham excedido o número de faltas previsto no art. 103, da lei estadual 3023 , de 15-7-37; para a execução desta deliberação, a Secretaria deverá encerrar a apuração da frequência no dia 10 de novembro;

- o Sr. Diretor consultou o Conselho sôbre se deveria convocar a Congregação para o dia 27 do corrente, nos termos do 
art. 24 da lei 3023, apesar de não se acharem lavradas as atas, por faliarem ao Sr. Secretário declarações de voto.

O Conselho entendeu que a sessão deverá ser convocada.

\section{5a. SESSÃO: 4-12-1952.}

Deliberou o Conselho:

- deferir, à vista do documento apresentado, o requerimento de um aluno do $2^{\circ}$ ano;

- indeferir, por falta de apoio legal, os requerimentos de vários alunos do Curso de Bacharelado;

- enviar, por cópia, aos srs. professores, o ofício e o temário do Congresso Nacional de Ensino Jurídico, a realizar-se em Fortaleza, de 9 a 19 de Julho de 1953 ;

- aplicar a pena de advertência a diversos alunos do $3^{\circ}$ ano, diante da informação do Prof. Soares de Mello, constante dos requerimentos em que os referidos alunos pedem novo exame de Direito Penal, do $3^{\circ}$ ano.

16a. SESSÃO: 12-12-19.52.

O Sr. Diretor fez várias comunicações ao Conselho sôbre o Curso de Doutorado e sôbre o orçamento para 1953, salientando o auxílio enérgico e eficiente, que recebera dos Profs. Cardozo de Mello Neto e Th. Monteiro de Barros Filho, na sessão do Conselho Universitário que tratara do orçamento.

Deliberou, ainda o Conselho:

- indeferir requerimentos de vários alunos, por falta de amparo legal, por não haver abono de faltas e por não mais terem aplicação os dispositivos do decreto lei 8019 , de $29-9-45$, respectivamente.

Aprovou o Conselho, contra um voto, o pedido do Prof. Almeida Jr., de contrato do Dr. Públio Salles Silva para colaborar nas aulas práticas de Medicina Legal, a partir de 1953;

- aprovar proposta do Prof. Ataliba Nogueira, no sentido de se oficiar ao Magnífico Reitor da Universidade, solicitando a sua intervenção para solucionar o assunto dos auxiliares de ensino;

- encaminhar ao Prof. Miguel Reale os papeis relativos à Casa do Estudante do Centro Acadêmico "XI de Agosto", e ofípio do 
Presidente do mesmo Centro, afim de que o referido professor apresente ao Conselho parecer sôbre o assunto.

\section{7.ఇ SESSÃO: $26-12-1952$}

Deliberou o Conselho: aluno;

— indeferir, por falta de apôio legal, o requerimento de um

- ficar ciente da resposta do M. Reitor sôbre os auxiliares de ensino.

- O Sr. Diretor fez diversas considerações ao Conselho sôbre os professores Barcia Trelles e Luigi Bagolini, terminando por propôr ao Conselho a renovação do contrato dos referidos professores em, 1953.

- Propôs ainda o Sr. Diretor o contrato do Prof. Beleza dos Santos, Diretor da Faculddae de Direito de Coimbra, para em 1953 fazer um curso de extensão universitária nesta Faculdade.

\section{PORTARIAS DO SR. DIRETOR}

Portaria n. ${ }^{\circ}$ 1/15, de 15-2-1952: - Designando D. Celina Christiano de Sousa para exercer as funções de Secretário da "Revista da Faculdade de Direito", a partir desta data, com a gratificação que' lhe competir, na forma da lei.

Portaria n. ${ }^{\circ}$ 2/15, de 10-3-1952: - Designando o Sr. Paulo Rodrigues de Carvalho para exercer as funções de servente diarista, a partir desta data.

Portaria n. ${ }^{\circ}$ 3/15, de 10-3-1952: - Designando D. Maria Wataghin para exercer as funções de servente diarista, a partir desta data.

Portaria n. ${ }^{\circ}$ 4/15, de 27-3-1952: - Nomeando o Dr. JOSÉ PINTO ANTUNES, pelo prazo de dez anos, a contar desta data, para o lugar de livre docentie da cadeira de Direito Constitucional, desta Faculdade, em virtude' de sua habilitação no concurso a que se procedeu neste Instituto, de 16 a 22 de Junho de 1951.

Portaria n. ${ }^{\circ}$ 5/15, de 8-4-1952: - Exonerando, a pedido, D. Daisy de Mello Leite, das funções de servente diarista, a partir desta data.

Portaria n. ${ }^{\circ}$ 6/15, de 5-5-1952: - Determinando que passem a ter exercício no Arquivo desta Faculdade as escriturárias Cloris 
Della Corte e Benedita Morato Proença, que serviam respectivamente no Seminário de Legislação Social e na Biblioteca da Faculdade.

Portaria n.o 6/15-A, de 21-5-1952: - Determinando que seja removido o escriturário Miguel Rogério de Freitas Guimarães, da Biblioteca para a Secretaria da Faculdade e diesignando D. Vera Ana Centim para desempenhar as funções que o referido escriturário desempenhava na Biblioteca.

Portaria n. $7 / 15$, de 21-5-1952: - Suspendendo, por sete dias, de acôrdo com o art. 140, letra "a", da lei 3023, de 15-7-1937, a partir de 20 de Maio, o servente diarista Orlando Caetano.

Portaria n. ${ }^{\circ}$ 8/15, de 26-5-1952: - Designando Da. Olga Giffoni para exercer as funções de servente diarista, a partir desta data.

Portaria n. ${ }^{\circ}$ 9/15 - Este número não foi usado.

Portaria n..$^{\circ}$ 10/15, de 27-6-1952: - Nomeando o Dr. JOSÉ LOUREIRO JUNIOR, pelo prazo de dez anos, para o lugar de livre docente da cadeira de Direito Constitucional, desta Faculdade, em virtude de sua habilitação no concurso a que se procedleu neste Instituto, de 2 a 7 de Dezembro de 1949.

Portaria n. 11/15, de 27-6-1952: - Suspendendo, por quinze dias, a partir de $10^{\circ}$ de Agosto corrente, nos termos do art. 141, $\S 10^{\circ}$, letra "d", da lei 3023, de 15-7-1937, o estudante Sebastião 'Tavares de Lima.

Portaria n. ${ }^{\circ}$ 11/15-A, de 14-7-1952: - Reconduzindo o Dr. Hilário Veiga de Carvalho, por mais dez anos, a partir desta data, no cargo de livre docente da cadeira de Medicina Legal, desta Faculdade, conforme foi requerido.

Portaria n..$^{\circ}$ 12/15, de 5-8-1952: - Fixando normas, que deverão ser obedecidas por todos os funcionários desta Faculdade, de acôrdo com art. 17, letra $\mathrm{K}$, lei 3023, de 15-7-1937:

- Ao Sr. Secretário compete exercer a polícia acadêmica, não só dentro da Secretaria, fazendo sair os que perturbarem a boa ordem dos trabalhos, como, em geral, em todas as dependências do estabelecimento, fiscalizando o serviço dos empregados, afim de dar circunstanciadas informações ao Diretor;

- Na ausência do Diretor, nenhum dos empregados poderá abandonar o serviço antes de terminar a hora do expediente, sem consentimento do secretário, ao qual dará os motivos porque precisa retirar-se, afim de que êste, quando comparecer o Diretor, lhe faça a necessária comunicação;

- Aos inspetores de alunos cumpre manter o silêncio nas salas de aula e em suas proximidades, velar pela boa ordem no 
edifício e fazer a verificação da presença dos alunos em aula, anotando as faltas e comunicando-as ao professor.

Portaria n..$^{\circ}$ 13/15, de 13-0-1952: - Designando D. Deyse Costa Xavier para exercer as funções de' servente diarista desta Faculdade, a partir desta data.

Portaria n. ${ }^{\circ}$ 14/15. de 13-8-1952: - Designando o Sr. Cyrilo Castro para exencer as funções de servente diarista desta Faculdade, a contar desta data.

Portaria n. ${ }^{\circ}$ 15/15, de 18-8-1952: - Concedendo, de acôrdo com art. 153, n. $^{\circ}$ VIII, do decreto-lei n..$^{\circ} 1713$, de 28 de Outubro de 1939 , trinta dias de licença, para tratamento de saúde, ao Prof. Jorge Americano, conforme requereu.

Portaria n. $16 / 15$, de 25-9-1952: - Suspendendo, por trinta dias, o livre docente José Dalmo Fairbanks Belfort de Mattos, do exercício de suas funções, nos termos do art. 138, letra "e", da lei n..$^{\circ} 3023$, de 15-7-1937, e de acôrdo com deliberação do Conselho Técnico-Administrativo, aprovada pela Congregação dos Professores desta Faculdade.

Docente livre Luis Eulalio de Bueno Vidigal - Substituiu, o prof. Gabriel de Rezende Filho na regência da cadeira de Direito Judiciário Civil do 5. ano. Designado pelo Magnífico Reitor para exercer um curso de Direito Judiciário Civil para os alunos do $30^{\circ}$ e do $50^{\circ}$ ano do curso de bacharelado. Nomeado pelo Sr. Governador para exercer, inteirinamente o cargo de professor catedrático de Direito Judiciário Civil do $33^{\circ}$ ano, na vaga decorrente do falecimento do prof. S. Soares de Faria.

Professor Miguel Reale - Afastado da regência da cadeira afim de representar a Faculdade de Direito no Congresso Internacional de Filosofia, do Instituto de Filosofia da Universidade de Roma. Designado para reger, cumulativamente com o seu cargo, a cadeira de Filosofia do Direito do $22^{\circ}$ ano do Curso de Doutorado. Nomeado para exercer as funções de Membro do Conselho Técnico-Administativo desta Faculdade.

Docente livre Alfredo Buzaid - Designado para ministrar um curso especializado de Direito Civil aos alunos do $3 .^{\circ}$ e do $5 .^{\circ}$ anos do Curso de Bacharelado. Designado para reger, no curso noturno, a cadeira de Direito Judiciario Civil, do $3 .^{\circ}$ ano. Afastado por noventa dias, afim de realizar uma viagem de estudos pela Alemanha.

Professor Noé Azevedo - Dispensado, a pedido, da regêncla da cadeia de Criminologia do $10^{\circ}$ ano do Curso de Doutorado. Designado pelo Magnifico Reitor, juntamente com outros, dos demais institutos universitários, para integrarem a Comissão 
Organizadora do Congresso das Universidades, a se realizar em São Paulo em 1954, como parte das comemorações do IV Centenário da Cidade e XX Aniversário da Universidade. Afastado da regência da sua cadeira pała, a partir de 2 de maio, tomar parte no Congresso Hispano-Luso-Americano Penal e Penitenciário e na 3. ${ }^{a}$ Conferência da Internacional Bar Association realizados em Madri.

Professor Basileu Garcia - Designado para reger a cadeira de Criminologia do $10^{\circ}$ ano do Curso de Doutorado.

Docente livre Manoel Franciseo Pinto Pereira - Declarado funcionário estável, "ex vi" do art. 30, letra c do Ato das Disposições Transitórias da Constituição do Estado. A partir de 31 de março, em gôso de três meses de licença prêmio. Designado pelo Magnífico Reitor para reger, como substituto, a cadeira de Direito Civil do $3 .^{\circ}$ ano, enquanto durar o impedimento do Prof. Jorge Americano. Designado para reger a cadeira de Direito Internacional Privado, do $5 .^{\circ}$ ano do Curso de Bacharelado, enquanto durar o impedimento do Prof. Luis Antônio da Gama e Silva.

Professor Candido Motta Filho - Em afastamento por mais trinta dias, por ato do Magnífico Reitor, de 2 de Abril, para realizar na Europa viagem de observação da exata aplicação dos principios constitucionais, decorrentes das novas orientações politicas. Designado para, cumulativamente com o seu cargo, substituir o prof. Mario Masagão na regência da cadeira de Direito Administrativo, no $50^{\circ}$ ano do curso de Bacharelado.

Professor José Soares de Mello - A partir de 14 de abril, em gôso de três mêses de licença-prêmio. Designado para, juntamnete com outros, e sob a presidência do Magnífico Reitor, retribuirem a visita da Embaixada Acadêmica de Coimbra. A partir de 25 de agôsto, em gôso de dois meses dé licença-prêmio.

Professor Sampaio Dória - Por ato do Magnífico Reitor, de 23 de Abril, em afastamento durante três meses para empreender viagem aos Estados Unidos da América do Norte, a fim de estudar a organização das Faculdades de Direito.

Professor Cardozo de Mello Neto - A partir de 5 de maio, em gôso de dois meses de licença-prêmio. A partir de 6 de agôsto, em gôso de cinco meses de licença-prêmio, em prorrogação.

Professor Cesarino Junicr - Afastado da regência da cadeira a partir de 1.0 de juho, para realizar viagem de estudos à Alemanha e Austria, bem como conferenciar em Paris com o professor François Perroux, e em Bruxelas, com os professores Van Goethem e Geysen. Designado para substituir o prof. Sampaio 
Dodia na regência da cadeira de Economia e Legislação Social do 2. ano do Curso de Doutorado. Designado para substituir - Prof. Cardozo de Mello Neto na regência da cadeira de Economia Politica do $1 .^{\circ}$ ano do Curso de Bacharelado.

Docente Livre José Dalmo Fairbanks Belfort de Mattos - Nomeado por decreto do Sr. Governador para substituir o Prof. Braz de Sousa Arruda, a partir de 22 de Abril.

Professor Sebastião Soares de Faria - Designado para substituir o Prof. Cardozo de Mello Neto por atos de Magnífico Reitor, de 14 de maio, e 19 de agôsto.

Docente livre Silvio Marcondes Machado - Nomeado por decreto do Sr. Grovernador para substituir o Prof. Ernesto Leme na regência da cadeira de Direito Comercial do $2 .^{\circ}$ ano do Curso de Bachareladio, enquanto durar o afastamento concedido a êste professor.

Docente livre Esther de Figueiredo Ferraz - Nomeada por decreto do Sr. Governador para substituir o Prof. Noé Azevedo na regência da cadeira de Direito Penal do $20^{\circ}$ ano do Curso de Bacharelado.

Docente livre Flavio Queiroz de Moraes - Nomeado pelo Sr. Governador para substituir o Prof. José Soares de Mello na regência da cadeira de Direito Penal do $3 .^{\circ}$ ano do curso de Bacharelado.

Professor Braz de Sousa Arruda - Designado para, a partir de 2 de maio, exercer cumulativamente com o seu cargo, a regência da cadeira de Direito Internacional Público do $2 .^{\circ}$ ano do curso de Doutorado. Nomeado por decreto do Sr. Governador de 18 de junho, para exercer a função gratificada de Diretor da Faculdade de Direito.

Professor Alvino Lima - Nomeado por decreto do Sr. Governador de 18 de junho para exercer a função de Vice-Diretor da Faculdade de Direito.

Professor Jorge Americano - Nomeado para exercer as funções de Membro do Conselno Técnico-Administrativo, por ato do Magnífico Reitor.

Professor Spencer Vampré - Foi-lhe concedida mais a sexta parte de seus vencimentos a partir de 21 de Dezembro de 1948.

Professor Theotonio Monteiro de Barros Filho - Por despacho do Sr. Governador, foi-lhe concedido afastamento por quinze dias para comparecer, como assistente das classes de comércio, à reunião do Conselho Inter-Americano de Comércio e Produção, a realizar-se em Lima, Perú.

Docente Livre Luiz Antonio da Gama e Silva - Foi-lhe concedido afastamento afim de participar da reunião plenária do Instituto 
Hispano-Luso-Americano de Direito Internacional, a realizar-se em Coimbra.

Professor Honório Fernandes Monteiro - Foi-lhe concedido afastamento pelo prazo de três meses afim de empreender viagem cultural e de pesquizas pela Europa.

\section{CONTRATOS DE PROFESSORES ESTRANGEIROS}

Decreto do sr. governador, de 14 de janeiro: Contratando o Prof. Luigi Bagolini, da Universidade de Bologna, Itália, para, no periodo de $10^{\circ}$ de Agosto a 30 de Novembro corrente, realizar um Seminário de "Filosofia do Direito", nesta Faculdade.

Decreto do sr. governador, de 14 de janeiro: Contratando o Prof. Camilo Barcia Trelles, da Universidade de Santiago de Compostela, Espanha, para, nos meses de abril e maio, realizar um seminário de "Direito Internacional", nesta Faculdade.

Decreto do sr. Governador, de 30 de julho: Prorrogando, por trinta dias, o contrato do Prof. Camilo Barcia Trelles.

\section{COMEMORAÇõES E SOLENIDADES}

11 de Janeiro: - Solenidades de colação de grau dos bacharelandos de 1951.

às 9 horas: Missa solene;

às 20,30 horas: Sesisão solene no Salão Nobre.

1. de Abril: - Aula solene de abertura dos cursos jurídicos, proferida pelo Prof. Sampaio Dória, às 10 horas, no Salão Nobre.

11 de Agosto: - Solenidades comemorativas do $125 .^{\circ}$ aniversário da fundação dos Cursos Jurídicos no Brasil;

às 10 horas: Missa solene;

às 20,30 horas: Sessão solene da Congregação, na qual se procedeu à entrega do título de "doutor honoris causa" pela Universidade de São Paulo a S. Excia. O Dr. Raul Fernandes, que proferiu uma conferência. Falou em nome da Congregação, o Prof. Vicente Ráo e em nome dos estudantes, um representante to Centro Acadêmico "XI de Agosto". 
8 de Novembro: - Missa mandada celebrar pela Congregação, por intenção da alma do Prof. Soares de Faria, no $30^{\circ}$ dia do seu falecimento, às 9 horas, na Igreja de São Francisco.

Às 10 horas, houve sessão em memória do Prof. Soares de Faria, na Sala João Mendes Jr., tendo feito o elogio fúnebre o Prof. Gabriel de' Rezende Filho.

14 de Novembro: - Aula solene de encerramento do curso jurídico, no corrente ano letivo, proferida pelo Prof. Alvino Lima.

\section{ALUNOS MATRICULADOS EM 1952 NO CURSO DE BACHARELADO}

\section{CURSO DIURNO}

1. Ano: Alunos sem dependência Sexo masc. Sexo fem. TOTAL Alunos dependentes

\begin{tabular}{|c|c|}
\hline 300 & 57 \\
\hline 216 & 24 \\
\hline $\mathbf{5 1 6}$ & 81 \\
\hline
\end{tabular}

2. Ano: Alunos sem dependência

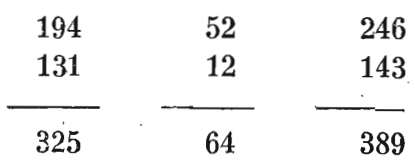

3. Ano: Alunos sem dependência \begin{tabular}{rrr}
303 & 54 & 357 \\
111 & 7 & 118 \\
\hline 414 & 61 & 475
\end{tabular}

4. Ano: Alunos sem dependência Alunos dependentes

\begin{tabular}{rrrr}
153 & & 15 & 168 \\
24 & & 1 & 25 \\
\hline 177 & & 16 & 193
\end{tabular}

5. Ano: Alunos matriculados 


\begin{tabular}{|c|c|c|c|}
\hline \multicolumn{2}{|c|}{ Total geral de matriculas } & $\begin{array}{l}\text { Excluindo } \\
\text { dependências }\end{array}$ & $\begin{array}{c}\text { Total de } \\
\text { dependências }\end{array}$ \\
\hline 1. $\mathrm{ANO}:$ & 597 & 357 & 240 \\
\hline 2. ANO: & 389 & 246 & 143 \\
\hline 3. ${ }^{\circ}$ ANO: & 475 & 35.7 & 118 \\
\hline 4..$^{\circ}$ ANO: & 193 & 168 & 25 \\
\hline \multirow[t]{4}{*}{ 5. ${ }^{\circ}$ ANO: } & 270 & 270 & - \\
\hline & 1.924 & 1.398 & 526 \\
\hline & & & \\
\hline & 1.924 & & \\
\hline
\end{tabular}

\section{CURSO NOTURNO}

1. Ano: Alunos sem dependência

Sexo masc. Sexo fem. TÓTAL Alunos dependentes

\begin{tabular}{cccc}
144 & & 8 & 152 \\
113 & & 6 & 119 \\
\cline { 1 - 1 } 257 & & 14 &
\end{tabular}

2. Ano: Alunos sem dependência

\begin{tabular}{|c|c|c|}
\hline 110 & 7 & 117 \\
\hline 93 & 3 & 96 \\
\hline 203 & 10 & 213 \\
\hline
\end{tabular}

3. Ano: Alunos sem dependência

$\begin{array}{rrrr}197 & 10 & 207 \\ 113 & & 5 & 118 \\ 310 & & 15 & 325\end{array}$

4. Ano: Alunos sem dependência

\begin{tabular}{|c|c|c|}
\hline 127 & 7 & 134 \\
\hline 22 & 0 & 22 \\
\hline 149 & 8 & 156 \\
\hline
\end{tabular}

5. Ano: Alunos matriculados

$\begin{array}{lll}144 & 3 & 147\end{array}$


Total geral de matrículas

$\therefore \circ$ ANO: 271

2. ${ }^{\circ}$ ANO: 213

3. ${ }^{\circ}$ ANO: 325

4. ${ }^{\circ}$ ANO: 156

5. ANO: 147

1.112

1.112

\begin{tabular}{c}
$\begin{array}{c}\text { Excluindo } \\
\text { dependências }\end{array}$ \\
152 \\
117 \\
207 \\
134 \\
147 \\
\hline 757
\end{tabular}

Total de dẹpendências

119

96

118

22

355

757

355

1.112

\section{TOTAIS DOS DOIS CURSOS: DIURNO E NOTURNO}

$$
\begin{array}{rc}
\text { iotal geral de matrículas } \\
\text { 1. ano: } & 868 \\
2 .^{\circ} \text { ano: } & 602 \\
3 .^{\circ} \text { ano: } & 800 \\
4 .^{\circ} \text { ano: } & 349 \\
5 .^{\circ} \text { ano: } & 417 \\
& \\
& 3.036
\end{array}
$$

3.036
Excluindo dependências

509

363

564

302

417

2.155
Total de dependências

359

239

236

47

881

2.155

881

3.036

\section{CONCURSO DE HABILITAÇÃO REALIZADO EM 1952:}

Total de candidatos: $-808 \quad$ Sexo masculino: 721

Sexo feminino: 87

808

Candidatos que optaram pelo exame de inglês: 426

Candidatos que optaram pelo exame de francês: 382 
F.E.B. e F.A.B.:

21

Outros candidatos:

Candidatos enquadrados na lei 1.076, de 31-3-1950: 113

Outros candidatos:

\section{RESULTADOS DO CONCURSO DE HABILITAÇÃO:}

Total de candidatos aprovados: $\ldots . \ldots \ldots . . \ldots 418$

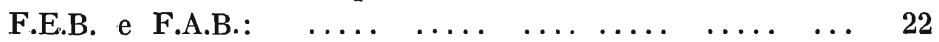

Desistentes e candidatos eliminados (enquadrados na

lei 1.076$): \ldots \ldots, \ldots \ldots \ldots \ldots, \ldots \ldots \ldots$

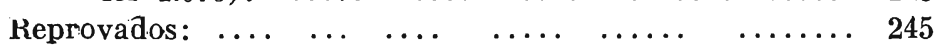

TOTAL: .... 808

CANDIDATOS APROVADOS: 418

Sexo masculino: 356

Sexo feminino: $62 \quad 418$

REPROVADOS: $\quad 245$

Sexo masculino: 232

Sexo feminino: $13 \quad 245$

CIJRSO DE DOUTORADO:
$10^{\circ}$ ANO:

CADEIRAS

CATEDRÁTICOS

DIREITO PUBLICO (Teoria Geral do Estado e Partes Especiais) .... ... Dr. Vicente Ráo

HISTORIA DO DIREITO NACIONAL .. D Dr. Walcemar Ferreira

DIREITO CIVIL COMPARADO ........ Dr. Lino Leme

CRIMINologia $\quad \ldots \quad \ldots \ldots \ldots \ldots \ldots$ Dr. Basileu Garcia 
2. ${ }^{\circ}$ ANO:

ECONOMIA E LEGISLAÇÃO SOCIAL .. Dr. Samraio Dória DIREITO PÚBLICO INTERNACIONAL ... Dr. Braz de S. Arruda FILOSOFIA DO DIREITO ... ... ... Dr. Miguel Reale

\section{MATRÍCULAS NO CURSO DE DOUTOPADO:}

1. ANO:

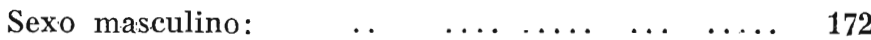

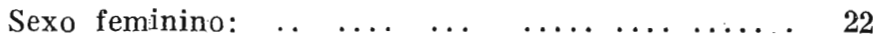

TOTAL DE NATRICULAS: $\ldots \ldots, \ldots 4$

2. $\mathrm{ANO}$ :

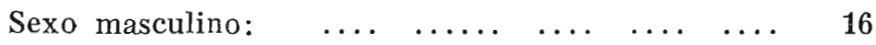

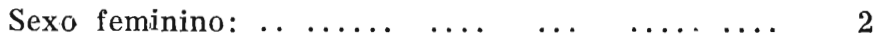

TOTAL DE MATRíCULAS: $\ldots \ldots \ldots 18$ 


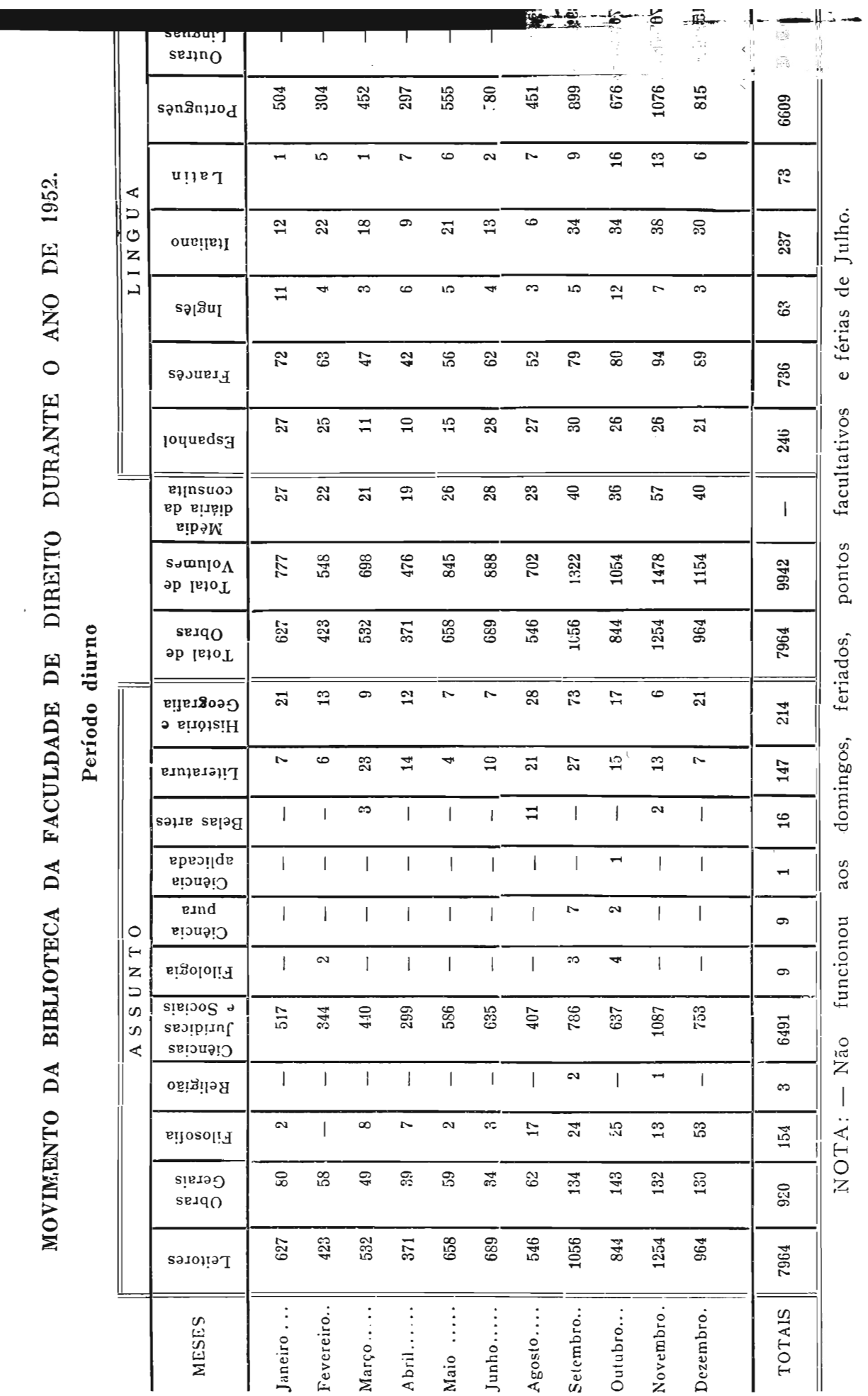




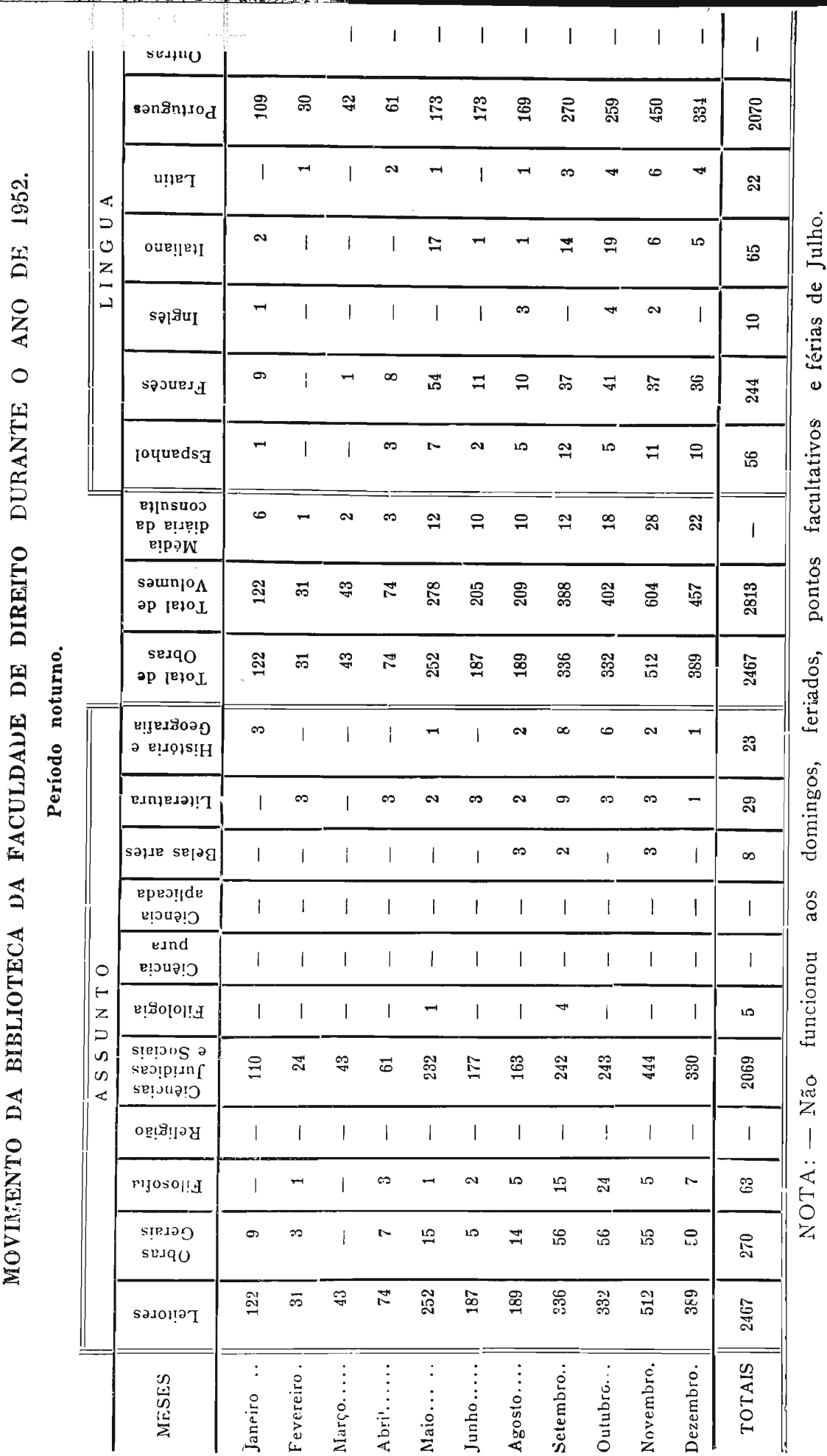




\section{BIBLIOTECA CIRCULANTE}

A Biblioteca Circulante da Faculdade de Direito teve, em 1952, o seguinte movimento:

Acêrvo: Foram registrados 1647 livros, subindo o total para 5874 obras registradas. O total de livros e revistas que a Biblioteca possui, subiu, assim, para perto de 8.000 volumes.

Foram adquiridos por compra 220 livros e por doação, 1427.

Os maiores doadores foram os professores Braz de Sousa Arruda, J. J. Cardozo de Mello Neto, Waldemar Ferreira e M. F. Pinto Pereira. Também enviaram doações as seguintes Faculdades de Direito: de Pôrto Alegre, Fortaleza, Belo Horizonte e Cidade do Salvador. Outras doações foram feitas pelo Consulado Americano, Biblioteca Central da Universidade de São Paulo, Instituto de Organização Racional do Trabalho. O embaixador José Carlos de Machado Soares também doou apreciável coleção de livros.

Preparo: Foram preparados 325.0 livros, subindo o total de obras prontas para circular a 5650 .

Inscrição: Inscreveram-se 585 leitores, sendo 367 no primeiro. semestre e 216 no segundo.

Empréstimos: O total de obras emprestadas foi de 10508, assim distribuidos por língua e por mês:

Por Lingua;

\begin{tabular}{c|c|r|r|r|r|r|r|c}
\hline & Port. & Fr. & Esp. & It. & Ing. & Al. & Outr. & Tot. \\
\hline Dir. & 6337 & 674 & 235 & 163 & 51 & 6 & 6 & 7472 \\
Geral & 8871 & 971 & 277 & 192 & 155 & 13 & 29 & 10508 \\
\hline
\end{tabular}


Por mês;

\begin{tabular}{l|c|c}
\hline & Dir e i t o & G e r al \\
\hline Janeiro .... & 354 & 437 \\
Fevereiro. & 231 & 327 \\
Março..... & 507 & 704 \\
Abril...... & 655 & 874 \\
Maio...... & 739 & 1042 \\
Junho..... & 850 & 1106 \\
Agosto.... & 682 & 1025 \\
Setembro... & 888 & 1362 \\
Outubro ... & 776 & 1186 \\
Novembro. & 989 & 1314 \\
Lezembro.. & 801 & 1131 \\
\hline T O T A L & 7472 & 10508 \\
\hline
\end{tabular}

Durante o mês de julho a Biblioteca permaneceu fechada.

Encadernação: Os serviços de encadernação foram todos executados na oficina da Faculdade de Direito.

\section{OBRAS EXECUTADAS NA FACULDADE}

1 - Galeria Paulista de Modas Ltda.

Sala de leitura da Biblioteca

2 - Cotim Comercial Técnica Importadora Ltda.

Sala de aula em aço "Conselheiro Crispiniano"

3 - Galeria Paulista de Modas Ltda.

Sala do Secretário

Hall de entrada da Sala da Secretaria

4 - Cotim Comercial Técnica Importadora Ltda.

Sala de aula em aço "Dino Bueno"

5 - J. P. Machado

Sala de aula "João Monteiro"

6 - J. P. Machado

Serviço nos 4 vitraux da Sala de Aula "Filosofia do Direito"

7 - J. P. Machado

Serviço de reforma e colocação de novos vitraux na Contadoria

$$
\text { e Tesouraria }
$$

8 - J. P. Machado

Sala nuva dos Bedeis 


\section{9 - J. P. Machado}

Requadros nas soleiras das entradas no Lgo. São Francisco e R. Riachuelo

10 - Reforma do Centro Acadêmico XI de Agosto:

J. P. MACHADO

GALERIA PAULISTA DE MODAS

COTIM

TECNOGERAL S/A COMERCIO E INDUSTRIA

\section{LICENÇAS, COMISSIONAMENTOS, DESIGNAÇõES, ETC., REFERENTES A FUNCIONARIOS DA FACULDADE}

Decreto do sr. Governador, de 6 de Fevereiro: Concedendo ao Sr. Antonio Letieri, servente desta Faculdade, duzentos dias de licença, em prorrogação, nos têrmos do art. 94 da Constituição do Estado.

Ato do magnífico Reitor de 13 de Fevereiro: Concedendo ao $\mathrm{Sr}$. Antonio Constantino, Bibliotecário Chefe desta Faculdade, afastamento pelo prazo de seis meses, afim de continuar prestando serviços junto à Secretaria de Estado dos Negócios do Govêrno.

Portaria n..$^{\circ}$ 14, do magnífico Reitor. de 14 de Fevereiro: Prorrogando, por um ano, o afastamento em que se encontra D. Maria Rita Franco Fonseca, afim de continuar à disposição desta Faculdade.

Ato do magnífico Reitor, de 21 de Fevereiro: Renovando, pelo prazo de dois anos, o contrato de D. Lourdes Negrão, afim de continuar prestando serviços técnicos junto à Biblioteca desta Faculdade.

Ato do magnífico Reitor, de 21 de Fevereiro: Contratando D. Maria das Dores de Carvalho Collet e' Silva para prestar serviços técnicos junto à Biblioteca Circulante desta Faculdade.

Decreto do Sr. Governador, de 5 de Março: Promovendo por antiguidade D. Cloris Della Corte, da classe "E" para a classe "F"

Decreto do Sr. Governador, de 5 de Março: Promovendo por antiguidade o Sr. Elias Apolinário Rodrigues, da classe "f" para a classe "g" da carreira de "inspetor de alunos"

Decreto do Sr. Governador, de 5 de Março: Promovendo por antiguidade, o Sr. Jerônimo Teixeira da Silva, da classe "g" para a classe " $r$ " da carreira de "inspetor de alunos"

Decreto do Sr. Governador, de 5 de Março: Promovendo por antiguidade, o Sr. José Martinho de Moura Baptista, da classe "g" para a classe "h" da carreira de "inspetor de alunos". 
Ato do magnífico Reitor, de 6 de Março: Renovando, pelo prazo de dois anos, o contrato de' D. Maria José da Luz Vaz, afim de continuar prestando serviços junto a esta Faculdade.

Decreto do Sr. Governador, de 19 de Março: Declarando competir ao Sr. Pedro Athanazio da Silva mais a sexta parte de vencimentos.

Ato do magnífico Reitor, de 27 de Março: Rescindindo, a pedido, o contrato de D. Delzie Ferraz de Camargo.

Ato do magnífico Reitor, de 2 de Abril: Contratando, pelo prazo de dois anos, D. Daisy de Mello Leite, para prestar serviços técnicos de contabilidade, junto a esta Faculdade

Decreto do Sr. Governador, de 22 de Abril: Promovendo, por merecimento, a partir de $10^{\circ}$ de Janeiro, o Sr. Pedro Arruda Mello, "inspetor de alunos".

Ato do magnífico Reitor, de 23 de Abril: Renovando o contrato de D. Celina Cristiano de Souza, afim de continuar prestando serviços técnicos junto à Biblioteca Circulante desta Faculdade.

Ato do magnífico Reitor, de 5 de Junho: Concedendo a. D. Ida Bottini três meses de licença, nos têrmos do art. 19 da lei 1309, de 29-11-51, combinado com o art. 168, do decreto-lei 12.273, de 28-10-41.

Decreto do Sr. Governador, de 23 de Junho: Prorrogando, pelo prazo de um ano, o exercício das funções de D. Célia Souza Queiroz do Amaral nesta Faculdade.

Decreto do Sr. Governador, de 25 de Junho: Promovendo, por merecimento, o Sr. Manoel da Silva, da classe "f" para a classe "g", da carreira de "artífice".

Decreto do Sr. Governador, de 25 de Junho: Promovendo, por antiguidade, o Sr. Leonardo Civolani da classe " $d$ " da carreira de "continuo", para a classe "e".

Decreto do Sr. Governador, de 10 de Julho: Apcsentando, a pedido, o Sr. Raul Assumpção Sampaio, no cargo de "chefe de secção"

Decreto do Sr. Governador, de 31 de Julho: Nomtando D. Maria Aparecida Silveira de Castro Gonçalves para exercer, em carater efetivo, o cargo de Chefe de' Secção, na vaga decorrente da aposentadoria do Sr. Raul Assumpção Sampaio.

Decreto do Sr. Governador, de 31 de Julho: Aposentando o Sr. Antonio Letieri no cargo de servente.

Ato do magnifico Reitor, de 8 de Agosto: Concedendo prorrogação de afastamento, pelo prazo de cento e oitenta dias, ao Sr. Antonio Constantino, Bibliotecário-Chefe desta Faculdade, afim de continuar prestando serviços junto à Secretaria de Estado dos Negócios do Govêrno. 
Portaria n. ${ }^{\circ} 64$ do magnífico Reitor, de 18 de Agosto: Pondo à dísposição da Reitoria D. Cloris Della Corte, funcionária da Faculdade.

Portaria n. 65 do magnífico Reitor, de 18 de Agosto: Pondo à disposição da Reitoria D. Neusenice de Azevedo Barreto, funcionária da Faculdade.

Portaria n. 66 do magnífico Reitor, de 18 de Agosto: Pondo à disposição da Reitoria o Sr. Cesar Pereira Viana, funcionário da Faculdade.

Portaria n. 67 do magnífico Reitor, de 18 de Agosto: Pondo à disposição desta Faculdade, o Sr. Alfredo Barone, funcionário da Reitoria.

Ato do magnífico Reitor, de 20 de Agosto: Prorrogando, pelo prazo de um ano, o contrato de D. Odila Jahyr de Oliveira, para continuar prestando serviços técnicos jụnto à Secretaria desta Faculdade.

Ato do magnífico Reitor, de 4 de Setèmbro: Concedendo três meses de licença prêmio ao Sr. Cesar Pereira Viana, com exercício na Reitoria.

Portaria n. 69 do magnífico Reitor, de 3 de Setembro: Colocando à disposição da Faculdade de Direito D. Nair Guimarães, funcionária da Reitoria.

Portaria do magnífico Reitor $n .^{\circ} 72$, de 11 de Setembro: Declarando sem nenhum efeițo a Portaria que pôs à disposição da Reitoria a funcionária D. Neusenice de Azevedo Barreto, em virtude de a interessada estar prestando serviços junto à Comissão de Participação do Estado nas Comemorações do IV Centenário de São Paulo.

Ato do magnífico Reitor, de 12 de Setembro: Concedendo a D. Cloris Della Corte' trinta dias de licença.

Portaria n. 78 do magnífico Reitor, de 26 de Setembro: Tornando sem efeito a Portaria n. ${ }^{\circ} 69$, de 3 de Setembro, que colocou à disposição desta Faculdade D. Nair Guimarães, funcionária da Reitoria.

Ato do magnífico Reitor, de 2 de Outubro: Concedendo ao Sr. Edgard Silvestre da Penha, inspetor de alunos desta Faculdade, três meses de licença-prêmio.

Ato do magnífico Reitor, de 5 de Outubro: Concedendo a D. Juracy Rosa Silvestre, diarista desta Faculdade, trinta dias de licença.

Ato do magnífico Reitor de 17 de Outubro: Concedendo a D. Cloris Della Corte trinta dias de licença, em prorrogação.

Portaria do magnífico Reitor $n .^{\circ} 84$, de 29 de Outubro: Prorrogando, pelo prazo de seis meses o afastamento em que se encontra 
D. Maria Rita Franco Fonseca, afim de que a mesma continue à disposição desta Faculdade.

Decreto do Sr. Governador, de 19 de Novembro: Declarando competir ao Sr. Mário Inácio Dilles, funcionário desta Faculdade, mais a sexta parte de seus vencimentos.

Ato do magnífico Reitor de 19 de Novembro: concedendo trinta dias de licença a D. Maria de Oliveira, extranumerário diarista desta Faculdade.

Ato do magnífico Reitor de 13 de Novembro: Concedendo trinta dias de licença, em prorrogação, a Dd. Juracy Rosa Silvestre, extranumerário diarista.

Ato do magnífico Reitor de 10 de Dezembro: Concedendo três mêses de ilcença-prêmio ao Sr. Cesar Pereira Viana, funcionário desta Faculdade, com exercício na Reitoria da Universidade.

Ato do 'magnífico Reitor de 16 de Dezembro: Contratando D. Vera de Almeida Sampaio para exercer as funções de Auxiliar Técnico junto a esta Faculdade.

Ato do magnífico Reitor de 16 de Dezembro: Renovando o contrato de D. Eunice Rocha Bueno de' Camargo, para que continue a prestar serviços técnicos junto a esta Faculdade.

Ato do magnífico Reitor de 16 de Dezembro: Renovando o contrato de D. Leontina Morato Proença, para que continue a prestar serviços junto a esta Faculdade.

Ato do magnífico Reitor de 16 de Dezembro: Prorrogando o contrato de D. Vera de Almeida Sampaio, levado a efeito para prestar serviços técnicos junto a esta Faculdade, até a data em que entrar no exercício das funções para as quais foi admitida por ato de 16 de dezembro.

Decreto do Sr. Governador de 29 de Dezembro: Nomeando o $\mathrm{Sr}$. Antonio Constantino para exercer o cargo de Diretor de Divisão, da PP-II, lotado na Secretaria de Estado dos Negócios do Govêrno, ficando exonerado, a partir da data em que entrar no execício das novas funçôes, do cargo de Bibliotecário-Chefe, desta Faculdade.

Ato do magnífico Reitor de 29 de Dezembro: Concedendo três meses de licença-prêmio ao Sr. Manoel Ribeiro de Almeida, servente desta Faculdade. 